\title{
PENGARUH CORPORATE GOVERNANCE, DAN FAKTOR-FAKTOR LAINNYA TERHADAP MANAJEMEN LABA
}

\section{FRISKA FIRNANTI}

\author{
STIE Trisakti \\ friska@stietrisakti.ac.id
}

\begin{abstract}
The objective of this research is to obtain empirical evidence of board of independence, institutional ownership, board of size, managerial ownership, profitability, firm size, audit quality, audit committee, and leverage as independent variables to earnings management. Earning management as dependent variable in Indonesian manufacturing companies.The research period is three years from 2012-2014 and population in this research is all listed companies in Indonesian Stock Exchange. Samples are obtained through purposive sampling method, listed manufacturing companies in Indonesian manufacturing companies meet the sampling criteria, resulting 185 data. Multiple linear regressions is used as the data analysis method in this research.The result of this research shows that profitability, firm size, audit quality, and leverage statistically have effect on the earningsmanagement. While other variables such as board of independence, institutional ownership, board of size, managerial ownership, and audit committee have no effect on earnings management.
\end{abstract}

Keywords: Earnings Management, Board of Independence,Institutional Ownership, Size, Board of Size, Managerial Ownership, Profitabilty, Firm Size, Audit Quality, Audit Committee, Leverage.

\begin{abstract}
Abstrak: Tujuan dari penelitian ini adalah untuk mendapatkan bukti empiris mengenai faktor-faktor yang mempengaruhi dewan komisaris independen, kepemilikan institusional, ukuran dewan komisaris, kepemilikan manajerial, profitabilitas, ukuran perusahaan, kualitas audit, komite audit, dan leverage sebagai variabel independen terhadap manajemen laba. Manajemen laba sebagai variabel dependen pada perusahaan manufaktur di Indonesia. Periode penelitian ini adalah 3 tahun dari 2012-2014 dan populasi penelitian ini adalah seluruh perusahaan yang terdaftar di Bursa Efek Indonesia dan perusahaan yang memenuhi kriteria sebanyak, 185 data. Metode penelitian dalam penelitian ini adalah regresi berganda. Hasil dalam penelitian ini adalah profitabilitas, ukuran perusahaan, kualitas audit, dan leverage memiliki pengaruh terhadap manajemen laba sedangkan dewan komisaris independen, kepemilikan institusional, ukuran dewan komisaris, kepemilikan manajerial, dan komite audit tidak memiliki pengaruh terhadap manajemen laba.
\end{abstract}

Kata kunci: Manajemen Laba, Dewan Komisaris Independen, Kepemilikan Institusional, Ukuran Dewan Komisaris, Kepemilikan Manajerial, Profitabilitas, Ukuran Perusahan, Kualitas Audit, Komite Audit, dan Leverage. 


\section{PENDAHULUAN}

Dalam beberapa dekade ini,corporate governance telah menjadi topik yang menarik untuk diteliti.Semua komponen dalam laporan keuangan yang dibuat oleh perusahaan merupakan alat ukur yang diperlukan oleh pemegang saham sebagai pertanggungjawaban manajemen (Beattie et al,1994 dalam Kusumaningtyas 2012).Terjadinya kasus keuangan diperusahaan publik berawal dari terdekteksi adanya tindakan manipulasi laporan keuangan, tindakan manajemen laba merupakan salah satu dampak dari lemahnya penerapan corporate governance Boediono (2005) dalam Effendi dan Daljono (2013).

Manajemen laba merupakan suatu permasalahan yang serius, karena rekayasa manajerial ini dapat merusak tatanan ekonomi, etika dan moral. Skandal kasus yang diketahui secara luas, seperti Enron, Merck, World Com dan mayoritas perusahaan lain di Amerika Serikat (Cornet et al, 2006 dalam Effendi dan Daljono 2013). Di Indonesia fenomena manajemen laba merupakan topik yang sering muncul, salah satu kasus yang terjadi akibat lemahnya penerapan good corporate governance seperti PT. Lippo Tbk dan PT. Kimia Farma Tbk. Penelitian ini telah menunjukkan bahwa manajemen laba semakin luas dan hampir ada dalam setiap pelaporan keuangan yang dilaporkan oleh perusahaan Boediono (2005) dalam Effendi dan Daljono (2013).

Healy dan Wahlen (1999) dalam Nugroho dan Eko (2011) menyatakan bahwa manajemen laba terjadi ketika manajemen menggunakan keputusan tertentu dalam pelaporan keuangan dan penyusunan transaksi-transaksi yang mengubah laporan keuangan. Tujuan hal ini untuk menyesatkan stakeholders tentang kondisi kinerja ekonomi perusahaan dalam penyajian laporan keuangan.

Penelitian ini merupakan pengembangan lanjutan dari penelitian yang sebelumnya telah dilakukan oleh Nugroho dan Eko (2011). Penelitian ini berusaha menyelidiki adanya praktik mana- jemen laba serta menguji kembali faktor-faktor yang mempengaruhi corporate governance. Selain itu, peneliti menambahkan variabel Leverage dalam penelitian ini (Guna dan Herawaty, 2010).

\section{Teori Keagenan}

Sutedi $(2012,13)$ mendefinisikan teori agensi dalam perekonomian modern, manajemen dan pengelolaan perusahaan semakin banyak dipisahkan dari kepemilikan perusahaan.Teori agensi menekankan pentingnya para pemegang saham menyerahkan pengelolaan perusahaan kepada tenaga-tenaga profesional yang disebut sebagai manajemen yang lebih mengerti dalam menjalankan bisnis sehari-hari dalam aktivitas yang dilakukan oleh perusahaan. Teori agensi merupakan dasar yang digunakan untuk memahami corporate governanceyang baik dalam sebuah perusahaan. Anthony dan Govindarajan (2003) dalam Azlina (2010) menyatakan konsep teori agensi merupakan sebuah hubungan atau kontrak antara principle (pemilik) dan agent (manajemen) yang timbul karena setiap pihak berusaha untuk mempertahankan tingkat kemakmuran.

Masalah agensi timbul dengan adanya konflik kepentingan antara pemegang saham dan manajer. Jensen dan Meckling (1976) dalam Kusumaningtyas (2012) menyatakan bahwa manajer sebagai pengelola perusahaan lebih banyak mengetahui informasi internal perusahaan dan segala kemungkinan yang akan terjadi di masa yang akan datang. Menurut Indriastuti (2012) bahwa teori agensi mengasumsikan bahwa manajer memiliki lebih banyak informasi dari pada investor,hal ini di karenakan investor tidak dapat mengamati kegiatan yang dilakukan manajer secara terus-menerus dan berkala. Investor tidak memiliki informasi yang cukup mengenai kinerja manajer, maka investor tidak pernah dapat merasa pasti bagaimana usaha manajer memberikan kontribusi pada hasil laporan keuangan perusahaan.

Jensen dan Meckling (1976) dalam Mursalim (2009) teori keagenan dapat dipandang sebagai suatu versi dari game theory, 
yang membuat suatu model kontraktual antara dua pihak atau lebih, dimana salah satu pihak disebut manajemen dan pihak yang lain disebut investor. Investor memberikan wewenang dan pertanggungjawaban atas pengambilan keputusan kepada manajer, hal ini dapat dikatakan bahwa investor memberikan suatu amanah kepada manajer untuk melaksanakan tugas tertentu sesuai dengan kontrak kerja yang telah disepakati.

Scott (1997) dalam Mursalim (2009) bahwa perusahaan memiliki banyak kontrak, misalnya kontrak kerja antara perusahaan dengan para manajernya dan kontrak pinjaman antara perusahaan dengan krediturnya. Kontrak kerja yang dimaksud yaitu kontrak kerja antara manajemen dengan pemegang saham untuk meningkatkan kemakmuran perusahaan dengan masing-masing informasi yang dimiliki. Manajemen memiliki informasi yang lebih banyak dibanding pemegang saham karena manajemen yang mengelola perusahaan secara langsung dan sering kali tindakannya bukan untuk memaksimumkan pemegang sahammelainkan untuk meningkatkan kesejahteraannya sendiri.

\section{Good Corporate Governance}

Sutedi $(2012,13)$ mendefinisikan bahwa munculnya konsep good corporate governance adalah jawaban atas ketidakpuasan ilmuwan keuangan atas kinerja teori agensi. Unsur-unsur yang membantu berlakunya good corporate governance tidak hanya dari teori agensi, melainkan bertambahnya informasi, transparansi, dapat dipertanggungjawaban (accountability), kejujuran (fairness), sustainability, jaminan hukum, serta hak-hak bagi pemegang saham. Teori agensi memberikan penjelasan bahwa lemahnya penerapan prinsip-prinsip dasar good corporate governance dapat menjadi kesempatan manajer untuk melakukan manajemen laba demi kepentingan diri sendiri, sehingga dapat merugikan para pemegang saham dan pihak terkait lainnya. Nugroho dan Eko (2011) menyatakan bahwa goodcorporate governance merupakan sebuah konsep dimana pengawasan manajemen terjadi dalam proses pengambilan keputusan, baik dalam organisasi publik maupun bisnis. Dalam proses pengambilan keputusan, tata kelola perusahaan harus dilaksanakan, sebagai salah satu persyaratan tegas dan terdengar oleh organisasi manajemen.

Menurut Herawaty (2008) good corporate governance merupakan konsep yang didasarkan pada teori keagenan, yang diharapkan dapat memberikan keyakinan kepada investor bahwa mereka akan menerima keuntungan atas dana yang mereka investasikan. Corporate governance jugaberkaitan dengan bagaimana investor yakin bahwa manajer tidak akan mencuri, menggelapkan atau menginvestasikan kedalam proyekproyek yang tidak menguntungkan dengan dana atau modal yang telah ditanamkan oleh investor dan bagaimana para investor mengendalikan para manajer (Shiefer dan Vishny 1997).

Syakhroza (2004) dalam Nugroho dan Eko (2011) menyatakan bahwa kualitas kepemimpinan (dewan komisaris dan dewan direksi) memainkan peran penting dalam tata kelola perusahaan. Dewan Komisaris bertindak sebagai pengawas perusahaan, sedangkan dewan direksi bertanggung jawab untuk kegiatan operasional perusahaan, kedua dewan tersebut memiliki tanggung jawab dan wewenang penuh dalam menentukan cara untuk mengarahkan, mengendalikan, dan mengawasi pengelolaan sumber daya sesuai dengan tujuan perusahaan.

Jensen dan Meckling (1976), Watt \& Zimmerman (1986) dalam Herawaty (2008) menyatakan bahwa laporan keuangan yang dibuat dengan metode pencatatan akuntansi diharapkan dapat meminimalkan konflik diantara pihak-pihak yang berkepentingan. Dengan laporan keuangan yang dilaporkan oleh manajemen sebagai pertanggungjawaban kinerjanya, para pemegang saham dapat menilai, mengukur dan mengawasi sampai sejauh mana manajemen tersebut bekerja untuk meningkatkan kesejahteraan bagi perusahaan. 


\section{Manajemen Laba}

Beberapa peneliti mendefinisikan manajemen laba dalam arti yang berbedabeda.Schipper (1998) dalam Nugroho dan Eko (2011) mendefinisikan manajemen laba sebagai "tujuan pengungkapan manajemen secara terbuka dalam proses pelaporan eksternal, dengan maskud memperoleh keuntungan pribadi". Healy dan Wahlen (1999) dalam Nugroho dan Eko (2011) menyatakan bahwa manajemen laba adalah sesuatu yang terjadi ketika manajer melakukan penilaian dalam penataan transaksi dan pelaporan keuangan. Penataan terhadap laporan keuangan tentu akan mengubah transaksitransaksi yang terjadi pada perusahaan, sehingga akan menyesatkan beberapa stakeholders tentang kinerja ekonomi perusahaan.

Fisher dan Rosenzweigh (1995) dalam Kusumaningtyas (2012) menyatakan bahwa manajemen laba sebagai tindakan manajemen dengan menyajikan laporan keuangan yang menaikkan atau menurunkan laba periode berjalan dari unit usaha yang menjadi tanggungjawabnya tanpa menghasilkan peningkatan profitabilitas ekonomi dalam jangka panjang Setiawati (2002) dalam Guna dan Herawaty (2010) menyatakan dalam proses pelaporan keuangan mendapat campur tangan manajemen dengan tujuan untuk menguntungkan dirinya sendiri. Caranya dengan mengubah laporan keuangan untuk mengelabui para pemegang saham dalam menilai prestasi kinerja ekonomi yang dicapai oleh perusahaan.Gumanti (2000) dalam Indriastuti (2012) menyatakan bahwa manajemen laba diduga muncul atau dilakukan oleh manajer atau para pembuat laporan keuangan dalam proses pelaporan keuangan dalam suatu organisasi karena mereka mengharapkan suatu manfaat atau keuntungan dari tindakan yang dilakukan oleh manajer atau para pembuat laporan keuangan.

\section{Dewan Komisaris Independen dan Manajemen Laba}

Dewan komisaris independen adalah anggota komisaris yang tidak terafiliasi dengan pihak manajemen. Keberadaan dewan komisaris independen dalam perusahaan berfungsi sebagai penyeimbang dalam proses pengambilan keputusan agar memberikan perlindungan terhadap pemegang saham minoritas dan pihakpihak lain yang terkait dengan perusahaan (Guna dan Herawaty 2010).Dechow et al. (1996) dalam Herawaty (2008) menyatakan apabila memiliki dewan komisaris yang didominasi oleh manajemen, maka kemungkinan manajemen perusahaan untuk memanipulasi laba akan lebih besar. Dalam hal ini jika struktur dewan komisaris berasal dari luar perusahaan tindakan memanipulasi laba akan berkurang.Johari dkk. (2008) dalam Setiawan dan Yuyetta (2013) menyatakan bahwa salah satu mekanisme yang efektif dalam mengawasi proses akuntansi adalah dengan memiliki dewan komisaris. Dewan komisaris harus terdiri dari dewan komisaris independen yang kemungkinan dapat mengurangi terjadinya kecurangan pelaporan keuangan dan mengawasi tindakan manajemen. Hipotesis yang diajukan adalah:

$\mathrm{H}_{1}$ : Dewan komisaris independen mempunyai pengaruh terhadap manajemen laba.

\section{Kepemilikan Institusionaldan Manajemen Laba}

Kepemilikan institusional merupakan kepemilikan saham perusahaan oleh institusi keuangan seperti asuransi, bank, dan dana pensiun. Tingkat kepemilikan yang tinggi akan meningkatkan usaha pengawasan yang lebih besar, sehingga dapat menghalangi perilaku manajemen untuk melakukan tindakan manajemen laba (Sari, Sutrisno, dan Sukoharsono 2013). Balsam et al.(2002) dalam Herawaty (2008) bahwa kepemilikan institusional sering disebut sebagai investor yang canggih. Karena investor institusional lebih dapat menggunakan informasi periode saat ini, dengan memiliki akses atas sumber informasi yang lebih tepat waktu dan relevan untuk memprediksi laba dimasa yang akan datang.

Effendi dan Daljono (2013) menyatakan bahwa Investor institusional tidak mudah diper- 
daya oleh manajemen laba yang dilakukan oleh manajemen perusahaan. Investor institusional dianggap memiliki kemampuan yang lebih baik untuk memonitor tindakan manajemen dibandingkan dengan investor individual, agar kegiatan yang dilakukan oleh manajemen perusahaan lebih transparan sebagai bentuk pertanggungjawaban terhadap pemegang saham.. Hipotesis yang diajukan adalah:

$\mathrm{H}_{2}$ : Kepemilikan institusional mempunyai pengaruh terhadap manajemen laba.

\section{Ukuran Dewan Komisarisdan Manajemen Laba}

Manajemen bertindak sesuai dengan keinginan investor yang dipengaruhi oleh tingkat kepemilikan saham perusahaan dalam manajemen itu sendiri. Manajer yang memiliki saham dalam perusahaan memiliki tujuan yang sama dengan pemegang saham lainnya Jensen dan Meckling (1976) dalam Nugroho dan Eko (2011). Menurut Wardhani (2007) bahwa ukuran dewan komisaris berperan dalam melakukan monitoring terhadap kinerja direksi. Dimana direksi adalah pihak yang mengelola operasional perusahaan yang merupakan penanggung jawab utama dalam tingkat keberhasilan perusahaan. Prastiti dan Meiranto (2013) menyatakan bahwa mekanisme pengendalian intern tertinggi adalah dewan komisaris yang bertanggungjawab untuk memonitor tindakan manajemen puncak. Pengawasan yang dilakukan agar tindakan manajer untuk melakukan manajemen laba berkurang sehingga investor memberikan kepercayaan untuk menanamkan modal pada perusahaan. Hipotesis yang diajukan adalah:

$\mathrm{H}_{3}$ : Ukuran dewan komisaris mempunyai pengaruh terhadap manajemen laba.

\section{Kepemilikan Manajerial dan Manajemen Laba}

Susiana dan Herawaty (2005) dalam Guna dan Herawaty (2010) menyatakan bahwa kepemilikan manajerial yakni saham yang dimiliki oleh manajemen secara pribadi. Investor manajemen memiliki insentif yang kuat untuk mendapatkan informasi mengenai perusahaan untuk memenuhi tanggungjawab serta untuk meningkatkan kinerja mereka. Menurut Zeptian dan Rohman (2013) menyatakan bahwa kepemilikan manajerial dapat digunakan untuk mengurangi konflik keagenan, sehingga mensejajarkan kedudukan manajer dengan pemegang saham. Masalah keagenan yang terjadi antara pihak manajemen dengan pemegang saham akan membuat manajer menuntut kompensasi yang tinggi sehingga meningkatkan biaya keagenan, sehingga konflik keagenan dapat diatasi dengan meningkatkan kepemilikan manajerial. Barus dan Sembiring (2012) menyatakan bahwa semakin banyak saham yang dimiliki oleh manajemen maka manajemen akan cenderung tidak mengatur labanya. Terdapat kesejajaran yang sama antara kepentingan manajer dan pemegang saham, sehingga keinginan untuk membodohi pasar modal akan berkurang, karena bukan hanya pemegang saham yang akan menanggung akibat dari memanipulasi laba tetapi pihak manajemen pun akan ikut menanggung baik dan buruknya dari setiap keputusan yang diambil..Hipotesis yang diajukan adalah:

$\mathrm{H}_{4}$ : Kepemilikan manajerial mempunyai pengaruh terhadap manajemen laba.

\section{Profitabilitasdan Manajemen Laba}

Sundjaja, Barlian, dan Sundjaja (2013, 189) mendifinisikan profitabilitas sebagai evaluasi kinerja perusahaan yang dihubungkan terhadap penjualan, aktiva, modal atau nilai saham. Pada laporan keuangan persentase penjualan dipakai untuk memudahkan evaluasi hubungan antara penjualan dan pendapatan untuk membandingkan kinerja perusahaan dari tahun ke tahun. Tampubolon $(2013,43)$ mendefinisikan bahwa tingkat profitabilitas dapat dilakukan untuk mengukur pendapatan menurut laporan rugi laba dengan nilai buku investasi. Profitabilitas tergantung dari informasi akuntansi yang diambil dari laporan keuangan yang kemudian digunakan oleh para manajer keuangan sebagai informasi untuk penilaian perusahaan dimasa yang akan datang. Gitman (2009) dalam 
Deitiana (2011) menyatakan bahwa profitabilitas yakni hubungan antara pendapatan dan biaya yang dihasilkan dengan menggunakan aset perusahaan, baik lancar maupun aset tetap dalam aktivitas produksi. Mengevaluasi keuntungan perusahaan dilihat dari sisi penjualan, aset, ataupun investasi pemilik dalam mengukur efektifitas manajemen serta kemampuan perusahaan dalam menghasilkan laba. Hipotesis yang diajukan adalah:

$\mathrm{H}_{5}$ : Profitabilitas mempunyai pengaruh terhadap manajemen laba.

\section{Ukuran Perusahaan Independen dan Mana- jemen Laba}

Razan dan Zingales (1995) dalam Sari dan Usman (2014) menyatakan bahwa ukuran perusahaan sering dijadikan tolak ukur bagi investor dalam melakukan investasi.Perusahaan besar cenderung lebih mampu memberikan informasi mengenai kondisi internal perusahaan yang dibutuhkan investor dari pada perusahaan kecil, sehingga investor dapat mempertimbangkan keputusan dalam berinvestasi. Zeptian dan Rohman (2013) menyatakan bahwa besar kecilnya perusahaan nampak dari nilai total aset perusahaan dan memiliki tingkat penjualan lebih besar. Tingkat kestabilan perusahaan yang lebih tinggi akan melibatkan banyak pihak, karena pengambilan keputusan yang dilakukan akan berpengaruh terhadap publik, sehingga masyarakat lebih mengenal perusahaan besar. Untari (2010) dalam Sari, Sutrisno, dan Sukaharsono (2013) menyatakan bahwa perusahaan besar akan mengungkapkan lebih banyak informasi dari pada perusahaan kecil. Perusahaan yang besar akan memiliki pemegang saham yang memperhatikan program sosial yang dibuat oleh perusahaan dalam laporan tahunan, hal ini merupakan media untuk menyebarkan informasi tentang tanggungjawab sosial dan lingkungan perusahaan. Hipotesis yang diajukan adalah:

$\mathrm{H}_{6}$ : Ukuran perusahaan mempunyai pengaruh terhadap manajemen laba.

\section{Kualitas Audit Independen dan Manajemen Laba}

Sanjaya (2008) dalam Indriastuti (2012) menyatakan bahwa hasil auditingakan terlihat dalam laporan keuangan yang disajikan oleh perusahaan. Kualitas audit yang digunakan yakni menggunakan ukuran Kantor Akuntan Publik, karena nama baik perusahaan (KAP) merupakan gambaran yang paling penting. Menurut Zeptian dan Rohman (2013) bahwa jasa auditor yang berkualitas merupakan upaya perusahaan untuk mengurangi perilaku manajemen untuk melakukan manajemen laba. Auditor yang berkualitas dan profesional memiliki tingkat kepercayaan masyarakat yang tinggi, sehingga oleh masyarakat auditor yang berkualitas dianggap memiliki tingkat ketelitian yang tinggi. Effendi dan Daljono (2013) menyatakan bahwa auditor yang bekerja di KAP Big Four dianggap lebih berkualitas. Auditor tersebut dibekali oleh serangkaian pelatihan dan prosedur yang dianggap lebih akurat dan efektif dibandingkan dengan auditor dari KAP non Big Four. Hipotesis yang diajukan adalah:

$\mathrm{H}_{7}$ : Kualitas audit mempunyai pengaruh terhadap manajemen laba.

\section{Komite Audit dan Manajemen Laba}

Zeptian dan Rohman (2013) menyatakan bahwa komite audit merupakan salah satu bentuk pengawasan yang dilakukan principal terhadap agent. Komite audit berfungsi sebagai pengawas, baik itu pengawasan terhadap proses pelaporan keuangan, manajemen risiko dan kontrol terhadap corporate governance. Menurut Effendi dan Daljono (2013) menyatakan bahwa komite audit dibentuk untuk meningkatkan kualitas laporan keuangan. Komite audit bermanfaat dalam menjamin transparansi, keterbukaan laporan keuangan, keadilan bagi stakeholders, dan pengungkapan informasi yang dilakukan oleh manajemen, dengan adanya pengawasan manajemen akan kehilangan kesempatan untuk melakukan tindakan curang terkait dengan laporan keuangan.Kosasih dan Widayati (2013) menyatakan bahwa komite audit berperan 
dalam mengawasi pihak manajemen agar tidak melakukan tindakan yang menguntungkan dirinya sendiri yang dapat merugikan pemilik perusahaan. Komite audit harus mempunyai pemahaman mengenai lingkungan bisnisnya terhadap risiko dan kontrol dalam pelaporan keuangan. Hipotesis yang diajukan adalah :

$\mathrm{H}_{8}$ : Komite audit mempunyai pengaruh terhadap manajemen laba.

\section{Leverage dan Manajemen Laba}

Gitman dan Zutter $(2010,533)$ menyatakan bahwa leverage merupakan pemberian pinjaman yang disediakan untuk perusahaan, adapun bunga yang dikenakan berdasarkan penilaian pemberi pinjaman terhadap risiko perusahaan. Tingkat pinjaman berdasarkan negosiasi kredit yang dilakukan oleh pemberi pinjaman dan perusahaan, setelah memperoleh pinjaman perusahaan dapat meningkatkan risiko dengan berinvestasi dalam proyek-proyek berisiko atau dengan menimbulkan hutang tambahan. Ma'ruf (2006) dalam Guna dan Herawaty (2010) menyatakan bahwa leverage adalah rasio yang menunjukkan besarnya aktiva yang dimiliki perusahaan yang dibiayai oleh hutang. Semakin tinggi nilai pinjaman maka risiko yang dihadapi investor semakin tinggi, sehingga investor akan meminta keuntungan yang semakin besar pada perusahaan. Barus dan Sembiring (2012) menyatakan perusahaan yang mempunyai rasio leverage tinggi memiliki proporsi hutang lebih tinggi dibandingkan dengan proporsi aktivanya, yang akan cenderung melakukan manipulasi dalam bentuk manajemen laba. Perusahaan dengan tingkat leverage yang tinggi cenderung mengatur labanya dibandingkan perusahaan dengan tingkat leverage rendah. Hipotesis yang diajukan adalah :

$\mathrm{H}_{9}$ : Leverage mempunyai pengaruh terhadap
manajemen laba.

\section{METODE PENELITIAN}

Sampel yang digunakan dalam penelitian ini adalah perusahaan manufaktur yang secara konsisten terdaftar di Bursa Efek Indonesia (BEI) pada tahun 2011 sampai dengan 2014. Pemilihan sampel dilakukan dengan metode purposive sampling yaitu pemilihan sampel berdasarkan kriteria tertentu sesuai dengan tujuan dan masalah penelitian. Prosedur hasil pemilihan sampel dapat dilihat pada tabel 1 berikut ini:

Tabel 1 Kriteria Pemilihan Sampel

\begin{tabular}{|c|c|c|}
\hline Kriteria Sampel & $\begin{array}{l}\text { Jumlah } \\
\text { Perusahaan }\end{array}$ & $\begin{array}{c}\text { Jumlah } \\
\text { Data }\end{array}$ \\
\hline $\begin{array}{l}\text { - Perusahaan manufaktur yang terdaftar di Bursa Efek Indonesia tahun } \\
2011 \text { sampai dengan tahun } 2014\end{array}$ & 130 & 390 \\
\hline $\begin{array}{l}\text { - Perusahaan manufaktur yang tidak menerbitkan laporan keuangan per } \\
\text { 31 Desember dari tahun } 2012 \text { sampai dengan tahun } 2014\end{array}$ & (4) & $(12)$ \\
\hline $\begin{array}{l}\text { - Perusahaan manufaktur yang tidak menerbitkan laporan keuangan dengan } \\
\text { satuan mata uang Rupiah dari tahun } 2012 \text { sampai dengan tahun } 2014\end{array}$ & $(26)$ & (78) \\
\hline $\begin{array}{l}\text { - Perusahaan manufaktur yang tidak menghasilkan laba bersih positif dari } \\
\text { tahun } 2012 \text { sampai dengan } 2014\end{array}$ & $(32)$ & (96) \\
\hline $\begin{array}{l}\text { - Perusahaan manufaktur yang tidak memiliki kepemilikan institusional } \\
\text { dari tahun } 2012 \text { sampai dengan } 2014\end{array}$ & (5) & $(15)$ \\
\hline - Jumlah sampel penelitian & 63 & 189 \\
\hline - Sampel yang dieliminasi karena merupakan outlier & - & (4) \\
\hline - Perusahaan manufaktur yang digunakan dalam penelitian & - & 185 \\
\hline
\end{tabular}


Definisi Operasional dan Pengukuran Variabel

Variabel dependen yang digunakan dalam penelitian ini adalah manajemen laba. Menurut Nugroho dan Eko (2011) manajemen laba merupakan kebijaksanaan atau penilaian dari manajer sebagai orang yang menyediakan laporan keuangan yang telah dimanipulasi.

Mengidentifikasi manajemen laba dalam penelitian ini menggunakan model m-Jones (1991) yang dimodifikasi oleh Dechow dan Sloan (1996) yang disebut sebagai model m-Jones, untuk memisahkan komponen non discretionary accrual (NDAC) dari komponen discretionary accrual (DAC), sebagaimana penelitian yang dilakukan oleh (Nugroho dan Eko, 2011). Tahap untuk mendapatkan nilai dari Discretionary accrual dinyatakan dalam persamaan sebagai berikut:

$$
\text { TACCit }=\text { NIit }- \text { CFOit }
$$

Keterangan:

TACC $_{\text {it }}=$ Total accruals perusahaan i pada periode $\mathrm{t}$

$\mathrm{Nl}_{\text {it }} \quad=$ Laba bersih operasi (net income) perusahaan i pada periode $\mathrm{t}$

$\mathrm{CFO}_{\text {it }}=$ Arus kas dari aktivitas operasi (operating cash flow) perusahaan $\mathrm{i}$ pada periode $t$

$$
\begin{aligned}
& \frac{T A C C i t}{T A_{t-1}}=\alpha_{1}+\left(\frac{1}{T A_{t-1}}\right)+\alpha_{2}\left(\frac{\Delta R E V t-\Delta R E C t}{T A_{t-1}}\right)+\alpha_{3}\left(\frac{P P E}{T A_{t-1}}\right)+\epsilon \\
& N D A C t=\alpha_{1}+\left(\frac{1}{T A_{t-1}}\right)+\alpha_{2}\left(\frac{\Delta R E V i t-\Delta R E C i t}{T A_{t-1}}\right)+\alpha_{3}\left(\frac{P P E}{T A_{t-1}}\right)+\epsilon \\
& D A t=\left(\frac{T A C C}{T A_{t-1}}\right)-N D A C_{t}
\end{aligned}
$$

Keterangan:

$\mathrm{NDA}_{\mathrm{i}, \mathrm{t}}=$ Non-discretionary accruals perusahaan $\mathrm{i}$ pada periode $\mathrm{t}$

$\alpha=$ Konstanta

$\mathrm{TA}_{\mathrm{it}-1}=$ Total aset perusahaan $\mathrm{i}$ pada periode $\mathrm{t}$

$\triangle \mathrm{REV}_{\mathrm{t}}=$ Perubahan pendapatan perusahaan $\mathrm{i}$ dari periodet ke peiode $\mathrm{t}-1$

$\triangle R C_{t}=$ Perubahan piutang perusahaan $\mathrm{i}$ dari periode $\mathrm{t}$ ke periode $\mathrm{t}-1$

$\mathrm{PPE}_{\mathrm{it}}=$ Aktiva tetap bruto perusahaan i pada periode $\mathrm{t}$

$\varepsilon_{\mathrm{it}} \quad=$ Sampel error perusahaan $\mathrm{i}$ pada periode $\mathrm{t}$

Dari persamaan-persamaan di atas, akrual diskresioner dapat dihitung dengan rumus:

$$
\text { DAit }=\frac{T A C C i t}{T A_{t-1}}-N D A C t
$$

Keterangan:

$\mathrm{DA}_{\text {it }}=$ Discretionary accruals perusahaan $\mathrm{i}$ pada periode $\mathrm{t}$

$\mathrm{TACC}_{\text {it }} / \mathrm{TA}_{\mathrm{t}-1}=$ Total accruals perusahaan i pada periode $\mathrm{t}$

$\mathrm{NDAC}_{\mathrm{t}}=$ Non-discretionary accruals perusahaan i pada periode $\mathrm{t}$ 
Dewan Komisaris Independen diberi simbol DKI. Dewan komisaris independen pengukuran yang digunakan adalah dengan skala rasio dari jumlah dewan komisaris independen dibandingkan dengan total anggota dewan komisaris dalam suatu perusahaan (Nugroho dan Eko 2011). Berikut adalah rumus yang digunakan:

$$
D K I=\frac{\text { Jumlah Dewan Komisaris Independen }}{\text { Total Anggota Komisaris }}
$$

Kepemilikan Institusional diberi simbol KMI. Kepemilikan institusional dapat diukur menggunakan skala rasio yang didapat dari jumlah saham yang dimiliki oleh investor institusi dibandingkan dengan total modal saham perusahaan yang beredar (Guna dan Herawaty 2010). Berikut rumus yang digunakan untuk variabel kepemilikan institusional:

$K M I=\frac{\text { Jumlah Saham Yang Dimiliki Investor Institusi }}{\text { Total Modal Saham Perusahaan Yang Beredar }}$

Ukuran Dewan Komisaris disimbolkan dengan UDK. Ukuran dewan komisaris dapat diukur dengan menggunakan sebuah ukuran dewan atau jumlah anggota dewan komisaris di sebuah perusahaan. Sebagai dewan komisaris yang menempati peringkat tertinggi dalam sistem manajemen internal, dewan komisaris bertugas mengawasi dan mengendalikan perusahaan (Nugroho dan Eko 2011), sehingga ukuran dewan komisaris diukur menggunakan skala rasio, dimana:

\section{UDK = Jumlah Anggota Komisaris Suatu Perusahaan}

Kepemilikan Manajerial diberi simbol KMJ. Kepemilikan manajerial yaitu jumlah saham yang dimiliki oleh manajemen, dewan direksi dan dewan komisaris. Tidak semua manajemen perusahaan mempunyai kepemilikan manajerial, maka dengan itu kepemilikan manajerial diukur menggunakan variabel dummy dengan skala rasio, dimana pengukuran yang digunakan dengan memakai penelitian (Nugroho dan Eko
2011) yang menyatakan 1 apabila perusahaan terdapat kepemilikan saham oleh manajerial dan 0 apabila tidak terdapat proporsi kepemilikan saham oleh manajerial.

Profitabilitas diberi simbol PROF. Profitabilitas merupakan kemampuan perusahaan dalam memperoleh laba (Guna dan Herawaty 2010). Dalam penelitian ini profitabilitas diukur menggunakan skala rasio, yaitu perbandingan antara laba bersih setelah pajak terhadap total aset, yang dapat dirumuskan sebagai berikut :

$$
\text { PROF }=\frac{\text { Laba Bersih Setelah Pajak }}{\text { Total Aset }}
$$

Ukuran Perusahaan diberi simbol UKP. Ukuran perusahaan diukur menggunakan Logaritma natural (Ln) dari total aset perusahaan (Guna dan Herawaty 2010). Total aset perusahaan digunakan sebagai pengukuran karena total aset perusahaan relatif lebih stabil dibandingkan dengan jumlah penjualan, berikut skala rasio yang digunakan:

\section{$U K P=L n($ total aset perusahaan)}

Kualitas Audit diberi simbol KLA. Kualitas audit mengunakan ukuran KAP.Auditor yang bekerja di KAP Big Four dianggap lebih profesional dan berkualitas dibandingkan dengan auditor dari KAP non Big Four (Zeptian dan Rohman 2013). Sehingga kualitas audit diukur menggunakan variabel dummy dengan skala rasio, yang menyatakan 1 untuk perusahaan yang diaudit oleh KAP Big Four, dan 0 untuk perusahaan yang diaudit oleh KAP non Big Four.

Komite Audit diberi simbol KMA. Komite audit adalah komite yang dibentuk oleh dewan komisaris sebagai bentuk pengawasan terhadap kinerja manajemen perusahaan (Nugroho dan Eko 2011). Komite audit diukur menggunakan skala rasio dengan total anggota komite audit yang dimiliki perusahaan. Berikut rumus yang digunakan adalah sebagai berikut:

KMA = Total Komite Audit Dalam Suatu Perusahaan 
Leverage diberi simbol LEV. Leverage menggunakan rasio debt to asset, yaitu total hutang dibandingkan dengan total aset yang dimiliki perusahaan pada akhir tahun (Agustia 2013). Rumus yang digunakan rasio leverage adalah sebagai berikut :

$$
L E V=\frac{\text { Total Hutang }}{\text { Toal Aset }}
$$

\section{Teknik Analisis}

Dalam penelitian ini metode analisis data yang digunakan adalah regresi berganda. Berikut persamaan regresinya:

$|D A|=\alpha+\beta_{1} D K I+\beta_{2} K M I+\beta_{3} U D K+\beta_{4} K M J+$ $\beta_{5} \mathrm{PROF}+\beta_{6} \mathrm{UKP}+\beta_{7} \mathrm{KLA}+\beta_{8} \mathrm{KMA}+\beta_{9} \mathrm{LEVe}$
Keterangan: |DA| Absolute Discretionary Acruals, DKI Dewan Komisaris Independen, KMI Kepemilikan Institusional, UDK Ukuran Dewan Komisaris, KMJ Kepemilikan Manajerial, PROF Profitabilitas, UKP Ukuran perusahaan, KLA Kualitas audit, KMA Komite audit, LEV Leverage, e Unsur pengganggu (error).

\section{HASIL PENELITIAN}

Analisa deskriptif dimaksudkan untuk memberikan gambaran mengenai suatu data yang dilihat dari nilai rata-rata (mean), median, minimum, maksimum, dan standar deviasi sebagai penjelasan atas variabel yang digunakan dalam penelitian. Hasil deskriptif dapat dilihat pada tabel 2 berikut ini:

Tabel 2 Statistik Deskriptif

\begin{tabular}{lrrrrr}
\hline & N & Minimum & Maximum & Mean & $\begin{array}{c}\text { Std. } \\
\text { Deviation }\end{array}$ \\
\hline DA & 185 & 0,0001 & 0,2352 & 0,053466 & 0,0436837 \\
DKI & 185 & 0,2000 & 1,0000 & 0,405869 & 0,1296213 \\
KMI & 185 & 0,3222 & 0,9824 & 0,707905 & 0,1699191 \\
UDK & 185 & 1 & 11 & 4,23 & 1,946 \\
KMJ & 185 & 0 & 1 & 0,46 & 0,500 \\
PROF & 185 & 0,0004 & 0,4268 & 0,097828 & 0,0910700 \\
UKP & 185 & 25,2767 & 33,0950 & 28,206073 & 1,6596483 \\
KLA & 185 & 0 & 1 & 0,45 & 0,499 \\
KMA & 185 & 2 & 5 & 3,09 & 0,426 \\
LEV & 185 & 0,0786 & 0,8809 & 0,410537 & 0,1747129 \\
\hline
\end{tabular}

Sumber: Hasil Pengolahan Data SPSS IBM 21

Tabel 3 Kepemilikan Manajerial (KMJ)

\begin{tabular}{lcc}
\hline \multicolumn{1}{c}{ Information } & Frequency & Percent \\
\hline $\begin{array}{l}\text { Tidak Terdapat } \\
\text { Kepemilikan } \\
\text { Manajerial }\end{array}$ & 100 & $54,1 \%$ \\
$\begin{array}{l}\text { Terdapat } \\
\text { Kepemilikan } \\
\text { Manajerial }\end{array}$ & 85 & $45,9 \%$ \\
\hline & & \\
\hline
\end{tabular}

Sumber: Hasil Pengolahan Data SPSS IBM 21 
Tabel 4 Kualitas Audit (KLA)

\begin{tabular}{lcc}
\hline \multicolumn{1}{c}{ Information } & Frequency & Percent \\
\hline $\begin{array}{l}\text { Di Audit Oleh KAP } \\
\text { Non Big Four }\end{array}$ & 102 & $55,1 \%$ \\
$\begin{array}{l}\text { Di Audit Oleh KAP } \\
\text { Big Four }\end{array}$ & 83 & $44,9 \%$ \\
\hline & 185 & $100 \%$ \\
\hline
\end{tabular}

Sumber : Hasil Pengolahan Data SPSS IBM 21

Tabel 5 Hasil Uji t

\begin{tabular}{lcccl}
\hline Variabel & B & T & Sig. & \multicolumn{1}{c}{ Kesimpulan } \\
\hline Constant &, 202 & 2,592 &, 010 & \\
DKI &,- 039 & $-1,553$ &, 122 & $\mathrm{Ha}_{1}$ tidak dapat diterima \\
KMI &,- 008 & $-0,419$ &, 676 & $\mathrm{Ha}_{2}$ tidak dapat diterima \\
UDK &, 001 & 0,603 &, 547 & $\mathrm{Ha}_{3}$ tidak dapat diterima \\
KMJ &,- 007 & $-1,136$ &, 257 & $\mathrm{Ha}_{4}$ tidak dapat diterima \\
PROF &, 083 & 2,072 &, 040 & $\mathrm{Ha}_{5}$ diterima \\
UKP &,- 007 & $-2,354$ &, 020 & $\mathrm{Ha}_{6}$ diterima \\
KLA &, 018 & 2,133 &, 034 & Ha diterima \\
KMA &,- 002 & $-0,201$ &, 841 & Ha tidak dapat diterima \\
LEV &, 115 & 5,769 &, 000 & Ha9 diterima \\
\hline
\end{tabular}

Sumber: Hasil pengolahan data SPSS IBM 21

Dari hasil uji t dapat diketahui bahwa nilai signifikansi variabel dewan komisaris independen (DKI) sebesar 0,122 yang berarti lebih besar dari $\alpha=0,05$. Dari hal tersebut dapat disimpulkan bahwa $\mathrm{Ha}_{1}$ tidak dapat diterima, yang berarti bahwa variabel dewan komisaris independen (DKI) tidak berpengaruh terhadap variabel manajemen laba (DA). Hal ini disebabkan bahwa dewan komisaris independen tidak dapat membatasi pengelolaan laba yang dilakukan oleh manajemen perusahaan. Pengangkatan komisaris independen dilakukan untuk pemenuhan pengawasan yang lebih baik terhadap manajemen, dengan adanya dewan komisaris independen tetap tidak dapat meminimalkan tindakan manajer dalam melakukan manajemen laba.
Variabel kepemilikan institusional (KMI) menunjukkan signifikansi sebesar 0,676 lebih besar dari $\alpha=0,05$. Hal ini menunjukkan bahwa $\mathrm{Ha}_{2}$ tidak dapat diterima, yang artinya variabel kepemilikan institusional (KMI) tidak berpengaruh terhadap variabel manajemen laba (DA). Hal ini disebabkan investor institusi yang memiliki saham cukup besar mempunyai kemampuan untuk terlibat dalam manajemen perusahaan, akibatnya manajer akan merasa terikat untuk memenuhi target laba, sehingga kepemilikan saham oleh investor institusional dapat menjadi kendala bagi perilaku manajer untuk melakukan manajemen laba.

Variabel ukuran dewan komisaris(UDK) menunjukkan nilai signifikansi sebesar 0,547 yang berarti lebih besar dari $\alpha=0,05$. Hal ini 
menunjukkan bahwa $\mathrm{Ha}_{3}$ tidak dapat diterima, yang berarti bahwa variabel ukuran dewan komisaris (UDK) tidak berpengaruh terhadap variabel manajamen laba (DA). Semakin besar jumlah anggota dewan komisaris maka semakin kecil terjadinya tindakan manajemen laba yang dilakukan. Hal ini membuktikan bahwa semakin banyaknya anggota dewan komisaris perusahaan maka akan memberikan pengawasan yang lebih efektif dalam mengawasi kinerja manajemen perusahaan dalam melakukan tindakan manajemen laba.

Variabel kepemilikan manajerial (KMJ) menunjukkan signifikansi sebesar 0,257 lebih besar dari $\alpha=0,05$. Hal ini menunjukkan bahwa $\mathrm{Ha}_{4}$ tidak dapat diterima, yang artinya variabel kepemilikan manajerial (KMJ) tidak berpengaruh terhadap variabel manajemen laba (DA). Hal ini disebabkan adanya kesetaraan kepentingan pemegang saham dan manajer, karena manajer yang memiliki saham di perusahaan cenderung mengambil kebijakan layaknya seseorang yang memegang kepentingan untuk meningkatkan kinerja perusahaan. Kegagalan pihak manajemen yang juga merupakan pemilik modal, sehingga manajemen mengambil keputusan dengan meningkatkan kualitas dalam proses pelaporan keuangan, karena persentase manajer sangat kecil jika dibandingkan dengan keseluruhan modal yang dimiliki investor umum.

Variabel profitabilitas (PROF) menunjukkan signifikansisebesar 0,040 yang berarti lebih kecil dari $\alpha=0,05$. Hal ini menunjukkan bahwa Hasditerima, yang berarti bahwa variabel profitabilitas (PROF) berpengaruh positif terhadap variabel manajemen laba (DA). Hal ini disebabkan bahwa profitabilitas memberikan pengaruh terhadap pihak manajer untuk melakukan tindakan manajemen laba. Perusahaan dengan tingkat profitabilitas yang tinggi akan membuat manajer mempunyai kesempatan untuk mengukur kemampuan perusahaan dalam menghasilkan laba, sehingga pihak manajer tertarik untuk melakukan tindakan manajemen laba.
Variabel ukuran perusahaan (UKP) menunjukkan nilai signifikansi sebesar 0,020 yang berarti lebih kecil dari $\alpha=0,05$. Hal ini menunjukkan bahwa $\mathrm{Ha}_{6}$ diterima, yang berarti bahwa variabel ukuran perusahaan (UKP) berpengaruh negatif terhadap variabel manajamen laba (DA). Semakin besar ukuran perusahaan maka semakin besar tindakan manajemen laba yang dilakukan. Hal ini menunjukkan bahwa semakin besar ukuran perusahaan maka perusahaan cenderung lebih diperhatikan oleh masyarakat dan lebih berhati-hati karena perusahaan besar dituntut dapat dipercaya dalam menyajikan laporan keuangan, sehingga akan meningkatkan dorongan manajemen perusahaan dalam melakukan tindakan manajemen laba.

Variabel kualitas audit (KLA) menunjukkan nilai signifikansi sebesar 0,034 lebih kecil dari $\alpha=0,05$. Hal ini menunjukkan bahwa Harditerima, yang berarti variabel kualitas audit (KLA) berpengaruh positif terhadap variabel manajemen laba (DA). Hal ini menunjukkan bahwa perusahaan yang diaudit oleh KAP BigFourmemiliki tingkat terjadinya manajemen laba yang tinggi, karena auditor ditunjuk untuk meningkatkan kepercayaan terhadap informasi laporan keuangan bukan untuk mendeteksi adanya manajemen laba. Adanya ketergantungan antara KAP dengan manajemen yang menyebabkan pengawasan yang dilakukan menjadi tidak maksimal, jika auditor melakukan pengawasan dengan ketat terhadap manajemen perusahaan dikhawatirkan KAP akan kehilangan klien yaitu perusahaan.

Variabel komite audit (KMA) menunjukkan nilai signifikansi sebesar 0,841 lebih besar dari $\alpha=0,05$. Hal ini menunjukkan bahwa $\mathrm{Ha}_{8}$ tidak dapat diterima, yang berarti variabel komite audit (KMA) tidak berpengaruh terhadap variabel manajemen laba (DA). Hal ini disebabkan komite audit dibentuk oleh dewan komisaris di perusahaan yang bersifat tidak independen serta lemahnya pengendalian dan pengawasan komite audit pada perusahaan yang mengaki- 
batkan munculnya kesempatan manajemen perusahaan untuk melakukan tindakan manajemen laba.

Variabel leverage (LEV) menunjukkan nilai signifikansi sebesar 0,000 yang berarti lebih kecil dari $\alpha=0,05$. Dari hal tersebut dapat disimpulkan bahwa Hag diterima, yang berarti variabel leverage (LEV) berpengaruh positif terhadap variabel manajemen laba (DA). Hal ini disebabkan besarnya tingkat leverage yang dimiliki perusahaan mengakibatkan suatu perusahaan kesulitan untuk memperoleh tambahan modal, maka perusahaan cenderung melakukan tindakan manajemen laba seperti mempercantik laporan keuangan perusahaan, sehingga dapat disimpulkan bahwa besarnya leverage merupakan salah satu faktor yang mendorong manajemen untuk melakukan tindakan manajemen laba.

\section{PENUTUP}

Berdasarkan hasil penelitian dapat diperoleh kesimpulan bahwa profitabilitas, ukuran perusahaan, kualitas audit, dan leverage berpengaruh terhadap manajemen laba. Sedangkan dewan komisaris independen, kepemilikan institusional, ukuran dewan komisaris, kepemilikan manajerial, komite audit tidak berpengaruh terhadap manajemen laba.

Keterbatasan penelitian ini adalah variabel independen yang digunakan hanya terbatas padadewan komisaris independen, kepemilikan institusional, ukuran dewan komisaris, kepemilikan manajerial, profitabilitas, ukuran perusahaan, kualitas audit, komite audit dan leverage. Periode pengamatan dalam penelitian ini hanya 3 tahun. Terdapat masalah regresi heterokedastisitas pada variabel dewan komisaris independen, kepemilikan manajerial, dan leverage.

Berdasarkan keterbatasan penelitian, kontribusi untuk penelitian selanjutnya adalah menambah variabel independen lainnya yang diharapkan berpengaruh terhadap manajemen laba seperti struktur modal. Untuk penelitian selanjutnya memperpanjang tahun penelitian sehingga diharapkan bisa mendapatkan hasil yang lebih akurat. Penelitian selanjutnya dapat menambah data untuk menghilangkan heteroskedastisitas.

\section{REFERENSI:}

Agustia, Dian. 2013. Pengaruh Faktor Good Corporate Governance, Free Cash Flow, dan Leverage Terhadap Manajemen Laba. Jurnal Akuntansi dan Keuangan, Vol. 15, No. 1, Mei 2013.

Anderson, David R, Dennis J. Sweeney, Thomas A. Williams, Jefrey D. Camm and James J. Cochran. 2014. Statistics For Business and Economics. The $12^{\text {th }}$ edition. Canada: South-Western, Cengange Learning.

Aygun, Mahmet., Suleyman Inc, and Mustafa Sayim. 2014. The Effets of Corporate Ownership Structure and Board Size on Earnings Management: Evidence From Turkey. International Journal of Business and Management, Vol. 9, No. 12.

Azlina, Nur. 2010. Analisis Faktor Yang Mempengaruhi Manajemen Laba.Pekbis Jurnal, Vol.2, No.3, November 2010: 355-363.

Barus, Andreani Caroline, dan Yosephine Natalia Sembiring. 2012. Faktor-Faktor Yang Mempengaruhi Motivasi Manajemen Laba Di Seputar Right Issue.Jurnal Wira Ekonomi Mikroskil, Vol. 2, No. 01, April 2012.

Deitiana, Tita. 2011. Pengaruh Rasio Keuangan, Pertumbuhan Penjualan Dan Dividen Terhadap Harga Saham. Jurnal Bisnis dan Akuntansi, Vol. 13, No. 1, April, 2011, HIm. 57-66.

Effendi, Sofyan dan Daljono.2013. Pengaruh Corporate Governance dan Kualitas Auditor Terhadap Manajemen Laba. Diponegoro Journal of Accounting, Vol. 2, No. 3, 2013, Hal: 1-14. 
Ghozali, Imam. 2013. Aplikasi Analisis Multivariate dengan program IBM SPSS. Semarang: Badan Penerbit Universitas Diponegoro.

Gitman, Lawrence and Chad J. Zutter. 2010. Principles of Managerial Finance. Thirteenth Edition. United States of America: Boston, Pearson Education Inc., Right and Contracts Departement.

Gunarti, Yuliana. 2015. Pengaruh Stuktur Kepemilikan, Return On Asset dan Leverage Terhadap Manajemen Laba. Jurnal Akuntansi dan Sistem Teknologi Informasi, Vol. 11, No. 1:9-16.

Gunawan, Ketut., Nyoman Ari Surya Darmawan, dan Gusti Ayu Purnamawati. 2015. Pengaruh Ukuran Perusahaan, Profitabilitas, LeverageTerhadap Manajemen Laba Pada Perusahaan Manufaktur Yang Terdaftar Di Bursa Efek Indonesia (BEI).e-Journal S1Ak Universitas Pendidikan Ganesha, Jurusan Akuntansi Program S1, Vol. 03, No. 1, 2015.

Guna, Welvin I, dan Arleen Herawaty. 2010. Pengaruh Mekanisme Good Corporate Governanace, Independensi Auditor, Kualitas Audit dan Faktor lainnya terhadap manajemen laba. Jurnal Bisnis dan Akuntansi, Vol. 12, No. 1, April, 2010, HIm. 53-68.

Herawaty, Vinola. 2008. Peran Praktek CorporateGovernance Sebagai Moderating Variable dari Pengaruh Earnings Management Tehadap Nilai Perusahaan. Jurnal Akuntansi dan Keuangan, Vol. 10, No. 2, November 2008, hal: 97-108.

Indriastuti, Maya. 2012. Analisis Kualitas Auditor dan Corporate Governance Terhadap Manajemen Laba. Eksistansi (ISSN 2085-2401), Vol. IV, No. 2, Agustus 2012.

Jao, Robert dan Gagaring Pagalung. 2011. Corporate Governance, Ukuran Perusahaan, Dan Leverage Terhadap Manajemen Laba Perusahaan Manufaktur Indonesia. Jurnal Akuntansi dan Auditing, Vol. 8, No. 1: 1-94.

Kosasih, Fransiska Natalia, dan Catur Widayati. 2013. Pengaruh Independensi Komite Audit, Efektivitas Komite Audit Dan Leverage Terhadap Praktik Manajemen Laba Pada Perusahaan di Sektor Industri Manufaktur Yang Terdaftar Di BEl Periode 2009-2011. Jurnal Akuntansi. Vol. XVII, No. 01, Januari 2013, hlm 132-148.

Kristiani, Kadek Emi, Ni Luh Gede Erni Sulindawati, dan Nyoman Trisna Herawati.2014. Pengaruh Mekanisme Corporate GovernanceDan Ukuran Perusahaan Terhadap Praktik Manajemen Laba Pada Perusahaan Manufaktur Yang Terdaftar Di BEl.e-Journal S1Ak Universitas Pendidikan Ganesha, Jurusan Akuntansi Program S1, Vol. 2, No. 1, 2014.

Kusumaningtyas, Metta. 2012. Pengaruh Independensi Komite Audit Dan Kepemilikan Institusional Terhadap Manajemen Laba.ISSN 1411-1497, Prestasi, Vol. 9, No. 1, Juni, 2012.

Mursalim. 2009. Analisis Persamaan Struktural: Aktivisme Institusi, Kepemilikan Institusional, Dan Manajerial, Kebijakan Dividen Dan Utang Untuk Mengatasi Masalah Keagenan. Jurnal Akuntansi dan Auditing Indonesia, Vol. 13, No. 1, Juni 2009, hlm 45-61.

Nugroho, Bernadus Y., and Umanto Eko. 2011. Board Characteristics and Earning Management. Bisnis \& Birokrasi, Jurnal IImu Administrasi dan Organisasi, ISSN 0854 - 3844, Accredited by DIKTI Kemendiknas RI No : 64a/DIKTI/Kep/2010, Vol. 18, No. 1, Januari 2011, hal 1-10.

Nugroho, Vidyarto. 2011. Pengaruh Struktur Kepemilikan Dan Komposisi Dewan Komisaris Terhadap Manajemen Laba.Jurnal Akuntansi, Vol. 11, No. 1, April2011, 415-430.

Prastiti, Anindyah dan Wahyu Meiranto.2013. Pengaruh Karakteristik Dewan Komisaris Dan Komite Audit Terhadap Manajemen Laba.Diponegoro Journal of Accounting, Vol. 2, No. 4, 2013, Hal: 1-12.

Purwanti, Rahayu Budhi dan Shiddiq Nur Rahardjo. 2012. Pengaruh Kecakapan Manajerial, Kualitas Auditor, Komite Audit, Firm Size dan Leverage Terhadap Earnings Management (Studi Empiris Pada Perusahaan Manufaktur yang Terdaftar di BEI Tahun 2008-2010). Diponegoro Journal of Accounting, Vol. 1 No. 1: 2-12.

Sari, Ati Retna., Sutrisno, dan Eko Ganis Sukoharsono. 2013. Pengaruh Kepemilikan Institusional, Komposisi Dewan Komisaris, Kinerja Perusahaan Terhadap Luas Pengungkapan Corporate Social Responsibility didalam Sustainabilty ReportPada Perusahaan Manufaktur Yang Terdaftar Di BEl. Jurnal Aplikasi Manajemen, Vol. 11, No. 3, September 2013.

Sari, Derry Permata dan Bahtiar Usman. 2014. Pengaruh Board StructureDanOwnership StructureTerhadap Firm Performance Pada Perusahaan Manufaktur Yang Terdaftar Di Bursa Efek Indonesia.e-Journal Manajemen Fakultas Ekonomi Universitas Trisakti, Vol. 1, No. 2, September 2014. 
Setiawan, Yudi dan Etna Nur Afri Yuyetta. 2013. Pengaruh Independensi Dewan Komisaris, Reputasi Auditor, Rasio Hutang, Dan Collateralizable AssetsTerhadap Kebijakan Deviden (Studi Empiris Pada Perusahaan Manufaktur Yang Terdaftar Di Bursa Efek Indonesia Periode 2009-2011.Diponegoro Journal of Accounting, Vol. 3 No. 1, Tahun 2013, Halaman: 1-11.

Suhartanto, Dwi. 2015. Pengaruh Ukuran Perusahaan, Profitabilitas, Leverage,Kepemilikan Publik, Perubahan Harga Dan Risiko Bisnis Terhadap Manajemen Laba Pada Perusahaan Publik Sektor Keuangan. Jurnal Ekonomi Bisnis, Vol. 20 No. 1, April 2015.

Sundjaja, Ridwan S, Inge Barlian, dan Putra Dharma Sundjaja. 2013. Manajemen Keuangan 1. Edisi 8 Catatan Ke-2. Jakarta: Literata Lintas Media.

Sutedi, Adrian. 2012. Good Corporate Governance. Edisi 1 Cetakan Ke-2. Jakarta: Sinar Grafika.

Swastika, Dwi Lusi Tyasing. 2013. Corporate Governance, Firm Size, and Earnings Management: Evidence in Indonesia Stock Exchange. IOSR Journal of Business and Management (IOSR-JBM), Vol. 10, May-Jun 2013: 77-82.

Tampubolon, Manahan P. 2013. Manajemen Keuangan (Finance Management). Jakarta: Mitra Wacana Media.

Wardhani, Ratna. Mekanisme Corporate Governance Dalam Perusahaan yang Mengalami Permasalahan Keuangan. Jurnal Akuntansi dan Keuangan Indonesia, Vol. 4, No. 1, hal.95-114.

Zeptian, Andra dan Abdul Rohman. 2013. Analisis Pengaruh Penerapan Corporate Governance, Struktur Kepemilikan, dan Ukuran Perusahaan Terhadap Manajemen Laba. Diponegoro Journal Akuntansi of Accounting, Vol. 2, No. 2, 2013, Hal: 1-11. 